\title{
The Influence of the Palestine Conflict on a Just Comprehensive and Lasting Peace in West Asia
}

\author{
Mohammad Saleh Bani Issa ${ }^{1}$ \\ ${ }^{1}$ Faculty of Arts \& Science, Department of Political Science, Middle East University, Amman, Jordan \\ Correspondence: Mohammad Saleh Bani Issa, Faculty of Arts \& Science, Department of Political Science, \\ Middle East University, P.O. Box 383 Amman 11831, Amman - Jordan. Tel: 96-279-670-4499. E-mail: \\ baniissa@hotmail.com
}

Received: September 13, 2012 Accepted: September 27, 2012 Online Published: November 29, 2012

doi:10.5539/jpl.v5n4p185

URL: http://dx.doi.org/10.5539/jpl.v5n4p185

\begin{abstract}
This study entitled "The Iinfluence of the Palestine Conflict on a Just Comprehensive and Lasting Peace in West Asia", aimed at studying and analyzing the reasons that stand behind not success and achieve real peace between the regional states in west Asia. This study also analyzes and assesses how the sides acted in their national self-interest.

The researcher reached into a point that there are many obstacles that prevented realize the peace in West Asia. Such obstacles are: the issue of Palestinian statehood, the issue of Jerusalem, the problem of refugees, the water scarcity problems, the arms proliferation and the nuclear issue, the environmental issue, the Golan Heights issue and the issue of fundamentalism.

The study reached into a point that if the west Asian region needs a Just Comprehensive and Lasting Peace, the sides must first of all go for searching solutions for all the said issues, otherwise the region will remain in its unstable situation for more coming decades, and will never reach into the mentioned peace.
\end{abstract}

This study contains of abstract, introduction, accurate analytical for each issues, conclusion and references.

Keywords: West Asia, peace process, Palestine issue, refugees, arms race, counters, Middle East, Arab Israeli conflict

\section{Introduction}

A peace process is an exercise whereby groups or countries with conflicting interests seek to avoid further confrontation through negotiations. Defining the concept of a peace process, Harold Saunders, a U.S. expert on regional affairs and the architect of such a process in the regional contact, said that "the peace process is more than conventional diplomacy and negotiation. It encompasses a full range of political, psychological, economic, diplomatic and military actions woven together into a comprehensive effort to establish peace between Israel and Arabs. Progress towards peace depends on breaking down the barriers to negotiation and reconciliation the other walls. If we ignore the politics of breaking down these barriers, the mediator and negotiator may never have a chance". (William B. Quandt, 1993: p. 3).

Conflicts threatening regional or international peace and security require their peaceful management and resolution. However, in order to launch a viable peace process it is essential that the parties involved should have substantial political will and determination and should be above suspicion to manage disputes through dialogue. Hence a peace process should largely be indigenous in nature with possible external assistance if desired by the parties concerned.

After years of stalemate, the peace process in West Asia has now reached a critical stage. Breakthroughs have been achieved in terms of steps taken for Arab-Israeli normalization like the PLO-Israeli accord of September 1993 and the Jordanian-Israeli agreement of 1994 (Alon Pines, 1994). A significant breakthrough was the regional peace process accord of 24th September 1995 when Israel and the PLO reached an accord to transfer West Bank areas to the Palestinian authority. (The West Bank Peace Plan, 1995).

The threats and challenges to the regional peace process are not insignificant. These emanate from the acts of hard-liners in Jewish and Palestinian communities like the sporadic attacks launched by Hamas and the 
assassination of Rabin by an ardent Israeli opponent of the peace process.

Hamas and some other Palestinian groups view the PLO-Israeli autonomy deal as a betrayal of the cause of Palestine. In Israel, hard-line group like the Likud bloc consider peace with the PLO contrary to the interest of Jewish settlers in the West Bank and a threat to Israel. In its essence, the Arab-Israeli peace process is hostage to the pressures from the extremist elements of the process and there is an urgent need to remove the major obstacles in this regard.

The peace process, as a function of diplomacy, is the management of what is possible within the given set of prevailing pre-conditions. Diplomacy does not necessarily create those conditions though it is forced to respond to them. These conditions, besides including variables like domestic environment as well as regional and global environment are also affected by the rhetorical pronouncements of various parties to the dispute that over the years assume the power of faith, so that any back-tracking on them is considered as surrender.

Today, the peace process has reached the difficult stage where diplomacy is confronted with obstinate and mutually irreconcilable positions of the parties. These issues are not only of peace and security-related confidence-building measures and a framework of bilateral and multilateral cooperation but also of more basic issues like sovereignty, territorial integrity and the legal status of the population involved. Those are the issues over which compromise, especially if perceived as reached under pressure, is considered as capitulation. A document that includes these clauses offering "peace" under a so-called peace process can have legality but not legitimacy.

As noted above, among the contracting parties in a peace process at inter-state level the following variables are closely interrelated: sovereignty over a well-defined territory and the authority over the population living there. In a peace process that is negotiated following an armed conflict, in which territory assumes crucial significance the return of the occupied territory to the state that has a legal claim over it under a mutually agreed formula, thus becomes the very basis of the peace process. That was the basis of the Egypt-Israel as well as Jordan-Israel peace accords.

In order to coordinate cooperation in security matters, a joint Israel-PLO coordination and cooperation committee has been established, which can recommend security policy guidelines and provide a channel for exchanging information between the sides. (Israeli-PLO "Agreement on the Gaza Strip and the Jericho Area, 1994) In the case of Israel and Jordan, this procedure is already a reality formalized by the peace treaty of 26 October 1994, (Jordan-Israel Peace: the Terms of the Peace Treaty, 1994) which calls for cooperation between the two countries against security threats of any kind, such as terrorism, subversion, or cross-boundary infiltration. It also envisages a conference on security and cooperation in the region to make the region free from weapons of mass destruction. (Jordan-Israel Peace: the Terms of the Peace Treaty, 1996).

There was a dispute over Israeli occupation of small areas that Jordan claimed to be its territory. Under the treaty, Jordan leased that territory to Israel on a 25-year lease. The lease was to be renewed automatically for the same period unless either party decided to terminate it. In return for these territorial concessions, Israel agreed to respect the special role of Jordan over the Muslim holy sites in Jerusalem.

As Jordan signed a peace treaty with Israel, many Arab countries thought that Jordan had betrayed them to Israel, but the late King Hussein didn't leave them to think negatively about peace in the region, when he said that "peace is a new factor in our lives in this region. This is a golden chance to join us in building peace and prosperity". (Newsweek, 1995, p: 38) On the closeness of Jordan's ties to Israel, the King said, "I don't think one can say it is an alliance. It is a meeting of minds in many areas". (Newsweek, 1995, p: 38) Jordan is not a client of any single external power, but has created interests in its survival among various regional and international actors. (Foreign Affairs, 1993, p:57). As King Hussein once declared "We stand to win or lose either way, victory or defeat will be our making, peace is not just a Jordanian choice, but also the choice of all other parties, it is the choice of peoples as much as we hope it to be the choice of leaders". (Jordan Times, 1998, p. 1).

Today, there is neither the will nor the ability to conclude an Israeli-Palestinian final status agreement that is peace. The PLO leadership fears it will lose support and, in the end, legitimacy, if it is seen to compromise important political goals. There is the additional fear that Hamas and other religious radical groups would gain at the expense of the PLO if anything were done to weaken the Palestinian claim to Jerusalem.

A radicalization of Palestinian and Israeli politics alike would mean that any chance for peace would be postponed if not destroyed. Deterioration in Israeli - Syrian relations could have equally serious consequences. Another war between these two antagonists could well involve weapons of mass destruction. Urban areas could become battlefields, civilians could become combatants. And this would entail staggering human and financial 
costs on both sides.

At a minimum, history shows that, thanks to deterrence, it is possible to maintain "no war, no peace" for extended periods. There is a level or plateau between a solution and peace on the one hand and collapse and conflict on the other. Establishing such a plateau and making it stable ought to be the purpose of the next stage of diplomacy.

\section{Issues of Final Status}

The issues of final status are the most difficult ones. If the sides would like to gain a just, comprehensive and lasting peace in west Asia, they have to find a logical solution to each of the following obstacles:

\subsection{The Issue of Palestinian Statehood}

In Israel there are both pro and anti Palestinian factions. While the former have advocated fair treatment to the Palestinians living under Israeli occupation. The Israeli governments have dealt with the local Arabs demand for independence or full autonomy. Israeli hard-liners not only reject limited self-rule for the People of Gaza and some West Bank towns but they also want to expel all Arabs from Israel and replace them with Jewish settlers. On the settlement issue, the late Rabin government was under extremist pressure not to accept the PLO's demand for independent status. The extremists totally rejected the idea of an independent Palestine state with its capital in East Jerusalem. On this issue no Israeli moderate or extremist is so far willing to compromise and denying the concept of a sovereign state.

There are three principal problems threatening meaningful statehood. First: is a severely reduced territory that may also be fragmented into noncontiguous pockets. Second: is the possibility of residual intermeshing of Israeli settler and Palestinian population concentrations, raising the prospect of mixed or overlapping jurisdictions, with attendant administrative, security and political complications. Third: are the limitations on the return of Palestinian refugees and the ceding of East Jerusalem to Palestinian sovereignty, without which the new state will lose much of its national identity and political legitimacy.

One might even ask how it is possible for the Palestinians to live with full-fledged statehood as it is likely to be structured in the given circumstances. A useful way to approach the question is to think in terms of security. Security has two distinct meanings in this context. In the narrow sense it means military defense against direct, physical threats to the population, vital economic installations or resources and agencies of the state. While in a broader sense it means the ability to protect "national values" identified broadly as safeguarding the political and territorial integrity of the state, ensuring the physical well-being and survival of the population, promoting economic welfare and preserving social harmony. (Edward Azar and Chung, 1988, pp. 383-84).

Security is in fact an integral concept that includes the military, political, social, economic and environmental dimensions. This understanding is at the heart of Palestinian insistence on exercising the right to selfdetermination in the form of a sovereign state. The Palestinian state would have limited military options fordealing with possible threats to its security even if it enjoyed unfettered freedom to build up its armed forces.(Ahmad Khalidi, 1992, pp. 6-8). But it could provide an effective mechanism for the regulation of bilateral relations and when necessary, the exercise of crisis management.

So, by partitioning the shared homeland into two distinct sovereignties, each people would be able to exercise self-determination and ensure its own survival in its own portion without endangering the other. Having obtained the key guarantees of security and sovereignty each state could afford to offer wider freedom of movement, employment, and residence to nationals of the other state. Special bilateral protocols would govern this movement, under which individuals would remain citizens of their original state but enjoy agreed rights as resident aliens in the other state. Their political participation would be limited to their own state. This would prevent a shift in the Arab-Jewish demographic balance that might allow either community to use legal or parliamentary means to subvert the two-state structure against the will of the other.

The Palestinian state will have little choice but to rely on the commitment of the international community to uphold its sovereignty and territorial integrity against external threats. In the interim, as the Palestinians have little ability to compel Israel to give up more, their principal means to obtain better terms will be to view sovereignty as a multi-faceted, multi-lateral attribute linked as far as possible to wider regional bodies as a means of hedging the state against Israeli domination.

The Arab attitude and that of the international community towards an independent Palestinian State is positive. Jordan is determined to pursue a durable, comprehensive and just peace that would lead to freedom. Late King Hussein said that "We will continue to support our brothers today and in the future, towards attaining the Palestinian people's legitimate rights and establishing their independent state on their national soil, with its 
capital in Jerusalem". (Jordan Times, 1997, p. 1)

The then infrastructure Minister, Ariel Sharon, said on 28 December 1996, that Israel must "soberly" accept the establishment of a Palestinian state. "We cannot hide our head in the sand, in the wake of the Oslo accords a Palestinian state is coming into existence". He added that the Palestinian entity created in 1994 already has "a Prime Minister, a government, parliamentary representation, an army and income tax all the elements of a state exist". (Jordan Times, 1997, p. 1) By his statement, Sharon raised hopes that despite the setbacks to the peace process, a successful conclusion war still possible.

Moreover, the then Israeli Prime Minister Shimon Peres said in Amman on July 13, 1998, that no solution would be effective without establishing a Palestinian state, as such a solution would not be just, comprehensive and lasting. If Israelis would like to protect their state, Peres said, so would the Palestinians who also needed a country. Thus, the final solution would be only to establish two countries. (Al-Ra'I, 1998, p. 1) Even the former Israeli Foreign Minister David Levi said that "the Palestinians are not a threat to Israel; that is not possible as there is no comparison between the Israeli Army and the Palestinian police (Al-Ra'i, 1998, p. 1).

Late Arafat who was under constant threat of a new Intifada, he expressed his intention to declare an independent Palestinian state in May 1999. Arafat has gone on record as saying : "We declared the Palestinian state at Algiers in 1988 and we are going to declare it again in 1999 on the Palestinian land; whosoever does not approve of this may drink from the Gaza Sea and the Dead Sea" (Al-Ra'I, 1998, p. 1).

More than a hundred countries have recognized Arafat's original declaration of independence, made from Algiers; and Israel fears that this number will increase if another declaration is made. The Palestinian Authority aims to set up an independent Palestinian state on the West Bank and the Gaza strip, with Israeli-occupied East Jerusalem as its capital. Moreover, Israel fears that the Arab-Israelis who number around one million represent a strategic threat to Israel. A report made public by then Israeli Prime Minister, said that the Israelis of Arab origin have several cultural and educational demands and may press for a self-rule. Hence the report emphasizes that establishing a Palestinian state might lead to a separatist and secessionist trends among the Arab Israelis (Al-Ayam, 1998, p. 1).

According to one report declared in 1997 said that the American administration has given the green light to the Palestinian Authority to declare their Palestinian state by May 1999, if the Palestinians and Israelis are unable by that time to reach a lasting settlement. And the U.S. has refused to accede to the Israeli demand to put pressure on the Palestinians to stop them. (Al-Mussawar, 1998, p. 3).

The former Labor Leader, Peres, has said that "nobody can change the fact that the Palestinians are on the way to independence". As well as the former leader, Ehud Barak has said that, "If we accept the right of self-determination for the Palestinians they should and probably will determine themselves as a Palestinian state" (Survey of Current Affairs, 1997, p. 257).

A vital question may rise by analysts, journalists, observers and politicians as the issue of the hour. The Palestinian Leaders confirm their determination to declare an independent Palestinian state. While time is running out, Israel confirms its sharp rejection of the idea an independent Palestine, and has threatened to re-occupy the Palestinian territories it has handed over to the Palestinian Authority, in case a Palestinian state is declared (Al-Akhbar, 1998, p. 9).

Analysts say that the time of declaring the establishment of a Palestinian state must be determined on the basis of accurate calculations. One group sees this as a logical step, because it is a natural and legal right for the Palestinian people, who have struggled for decades and lost scores of people in the process. Thus, according to the Oslo accords the declaration would be a right decision and there is high probability of wide measure of international recognition (Al-Akhbar, 1998, p. 9).

Another view is that circumstances are yet to mature in that the elements essential to a Palestinian state are not in evidence as yet, especially in view of the fact that the Palestinian Authority does not exercise sovereignty over the land. This view questions the basis on which the Palestinian Authority is preparing to establish a Palestinian state while its lands with all the requisite infrastructural facilities are fully in Israeli hands. Israel controls electricity, communication networks, water resources as well as the import and export of Palestinian flour and bread. In addition, the official currency in the Palestinian areas is the Israeli Shekel (Al-Akhbar, 1998, p. 9).

Furthermore, a large Palestinian labor force is still dependent on work inside the 'green-line' for a living. When the Palestinian areas are closed by the Israeli Army, which happens quite frequently for security reasons, the workers are barred from going to work inside Israel, thus standing to lose millions of dollars by way of daily earnings (Al-Akhbar, 1998, p. 9). 
If the Palestinian Authority is truly committed to declare an independent state then it must start immediately on political measures to separate completely from Israel and to get rid of Israeli occupation and of Jewish settlements in the Palestinian territories.

\subsection{The Issue of Jerusalem}

Jerusalem is another source of controversy between Israel and the PLO. Unlike hardliner Israeli elements who want Jerusalem to remain as an integral part of Israel, it has been suggested by some moderate Israeli groups that the city should be recognized as sacred by the followers of the three major religions, Islam, Christianity and Judaism. Signed by hundreds of prominent Israelis, a petition titled, "Our Jerusalem" notes that Jerusalem belongs alike to Israelis and Palestinians, to Muslims, Christians and Jews, that the city is a mosaic of all the periods and religions that have enriched it from antiquity and that an open and united Jerusalem must be the capital of the two states, west Jerusalem must be the capital of Israel, east Jerusalem the capital of Palestine (Leon, 1995).

Of course, East Jerusalem is a part of the occupied West Bank, and this point needs to be made over and over again, as it is integrally related to the whole issue of liberating Palestine from the burden of Israeli occupation.

Jerusalem must be the capital for both parties and the basis for this is the UN Partition Resolution of 1947. The UN Resolution called for Jewish and Arab states to be created side by side in Palestine and for Jerusalem to be an international city. So, no one can accept that Jerusalem will be under Israeli sovereignty; rather it must be under shared sovereignty, Palestinian on the Palestinian side and Israeli on the Israeli side.

It is widely expected that the talks on Jerusalem will be among the most complicated and difficult of all the issues to be dealt with in the "final status" negotiations. These negotiations will focus on the toughest issues, including the fate of Arab East Jerusalem that is claimed by sides, the question of Jewish settlers and the return of Palestinian refugees. (The Asian Age, 1996, p. 4)

The American position on the Jerusalem issue is not clear. However the then U.S. President Clinton has been quoted as stating that "I recognize Jerusalem as an undivided city, the eternal capital of Israel, and I believe in the principle of moving our embassy from Tel Aviv to Jerusalem" (Neff, 1995, pp. 15-16) Such a statement, if true, is not only unfair but casts a cloud over U.S. Sincerity in working towards a solution of the West Asian conflict.

The Arab position on Jerusalem is clear. The late Sheikh Zayed Ben Sultan of the UAE said "there would be no peace in the region of West Asia without the return of Arab East Jerusalem" (Jordan Times, 1997, p. 12) At the same time, the then Israeli Interior Minister Eli Euissa said, "We will fight with all our power in the war over Jerusalem, whether through this law or through the building and planning law or another law" (Gulf News, 1997, p. 17) The subject of Jerusalem will dominate the deliberations, especially as Israel has not taken any measures to halt the construction of Jewish settlements on Arab lands (Jordan Times, 1997, p. 3).

\subsection{The Problem of Refugees}

The Arab-Israeli conflict had the tragic result of forced migration and a refugee problem, an issue that has festered as an open wound at the root of the conflict. The personal and collective tragedy of refugees of all nationalities in the region, whether those of the 1948 conflict or of the later 1967 one, passed from one generation to the next and became a part of the reality of the West Asian region. Today, the problem of refugees is an obstacle that clouds the relations among nations of the region. In the interest of all who live in West Asia, the refugees must be provided full rehabilitation. More than two-thirds of the estimated six million Palestinians world- wide are refugees and displaced persons as a result of the 1948 and 1967 wars, the 1982 Israeli invasion of Lebanon and the Gulf War of 1991. According to the United Nations Relief and Works Agency (UNRWA), "Palestine refugee "shall mean person whose normal place of residence was Palestine during the period 1 June 1946 to 15 May 1948 and who lost both his home and means of livelihood as a result of the 1948 conflict (UN document, 1984). Subsequent to the 1948 crisis, Israel offered to take back 100,000 Palestinian refugees, a fraction of the more than 750,000 who fled or were driven from their homes during the fighting (Neil Caplan, 1982, pp. 25-26).

The Palestinians' right of return was linked, through General Assembly Resolution 3236 (XXIX) to their right of self-determination without external interference, the right to national independence and sovereignty. Palestinians thus have the right to return to their homes and properties (Antonio Cassese, 1993, pp. 10-13).

No one shall be arbitrarily deprived of the right to enter his own country (United Nations, 1978, p. 6) No one should be denied the right to return to his own country on the ground that he has no passport or other travel document. Regardless of whether Palestinians have a right to return to Israel, they have a right to return to 
Palestine (Donna Arzt and Karen Zughaid, 1993, p. 1445). Therefore, close to two- thirds of the American respondents endorsed the right of the Palestinian refugees to return to their homes in accordance with UN Resolutions (NJ: Gall Up Organization, 1992, pp. 1-4).

For many years now, the fate of the Palestinian refugees has been the subject of a Refugee Working Group (RWG) within the framework of the multilateral peace talks set up in the wake of the Madrid Conference of 1991.

In his opening presentation at the RWG Meeting held in November 1992, the first attended by the Israelis, the head of the Israeli delegation called a travesty the proposition that the "Palestinian refugee problem was the result of explosion". But he went on to say that "the Palestinian refugee problem was born as the land was bisected by the sword not by design, Jewish and Arab. It was largely the inevitable by-product of Arab and Jewish fears, and the protracted bitter fighting" (Shomlo Ben Ani, 1992, p. 3) This language echoes Israeli historian Benny Morris's well known formulation that the refugee problem was "born of war not of design". Still, the statement does acknowledge some Israeli responsibility for what the head of the Israeli delegation to the RWG called the "inherent immorality of war" (Shomlo Ben Ani, 1992, p. 5).

Citizenship and residency rights have been denied to Palestinian refugees everywhere in the Arab world except Jordan, the initial rationale being solidarity and the affirmation of the Palestinians' right of return to their homeland. Jordan of course, grants equal rights to Palestinians in health, education, employment and property ownership. In fact it spends more than $\$ 300$ million annually on them. Lebanon, Syria and Egypt, and lately the Gulf states, deny Palestinians the right to work, free education, health and freedom of movement (Abbas Shiblak, 1993).

The Israeli-PLO Declaration of Principles (DOP) of September 1993 stipulates the creation of an Israeli-PLO Committee (with the participation of Egypt and Jordan) to discuss the Palestinians displaced in 1967, while issues relating to the 1948 refugees are to be discussed in the "final status talks".

The DOP provides for discussion of the refugee issue once the interim period of self-rule gets underway. However, the long-standing Israeli position on right-of-return legislation (the Law of Return) is based on a collective - exclusive model. In other words, Israeli law bestows collective communitarian criteria for one group (Jewish immigrants) and individualist -liberal criteria on a selective basis for another group (Arabs) (Yoav Peled, 1992, pp. 432-43).

More than three million displaced Palestinians are currently living outside Israel and the occupied territories. Palestinian refugees are not seeking a place of residence other than their country of origin. Their main wish is to be allowed, should they so choose, to return to their own homeland.

Several steps should be taken if the Palestinians are to avoid total disaster on the refugee issue. First the Palestinians must forge coordination on this matter with other Arab countries, particularly Lebanon, Jordan, Syria, Iraq and Egypt. Any Palestinian policy of "going it alone", given Palestinian weakness vis-à-vis Israel, would be dangerous in the long run and indeed suicidal. Second and more importantly an honest, open debate on the refugee issue within the Palestinian refugee communities is absolutely essential. This should involve a free, independent plebiscite to determine how many refugees would actually want to exercise their right to return. In the meantime, part of the coordination with Arab host states would involve those Palestinian refugees who are unable or unwilling to return. The question of granting them citizenship of the host state would have to be settled. At a minimum, the Palestinian leadership should be able to guarantee that the refugees, wherever they reside, are granted Palestinian citizenship. Finally, it is essential that the leadership explore possible options and solutions from among the refugees themselves and that the latter are not faced with a fait accompli or coerced into accepting solutions not in their interest.

\subsection{Water Scarcity Problems}

After the Arab-Israeli wars and 'oil wars' the West Asian region may now be heading towards 'water wars'. The declining rainfall has caused near famine conditions in a number of West Asian countries and the trend towards relying on cash crops has further depleted the sub-soil water resources as well.

In mid 1980's American intelligence services agencies estimated that there were at least ten places in the world where war could break out over the dwindling availability of water resources. One of these is the West Asia region. Jordan, Israel and the Gulf Cooperation Council (GCC) countries are sliding into the perilous situation in which all available fresh surface and ground water supplies will be exhausted by the end of the century (Joyce R. Starr, 1991, p. 42).

Arabs have long believed that one of the Israeli objectives in its 1982 war in Lebanon was to gain access to the 
Litani River, which flows through the Israeli-occupied security zone in southern Lebanon (Fida Nassrallah, 1990, p. 16).

Israeli control over the entire western shore of the Dead Sea affords it greater access to mineral extraction and recreational opportunities (Saul Cohen, 1983, p. 29) Israel needs to secure its access to the water tables below the Judea foothills east of the 'green line', which supplies the coastal plain. To ensure Israeli access to this water would involve shifting the political boundary a few kilometers to the east of the 'green line', co -operating an area that currently houses a substantial Arab population (Saul Cohen, 1983, p. 30).

Thus, West Asian states and their populations are acutely aware of the water shortage. Water consumption here is comparatively lower than the available supply but fresh drinking water is scarce. The problem is how to make drinking water available at reasonable cost; and without effective cooperation among the regional states, it will not possible being to solve the regional water problem.

Thus, due to the seriousness of regional water problems, water issues must be treated in the Arab-Israeli and Palestinian-Israeli peace process, as part of the land-for-peace debate. The only hope for finding a just solution is through cooperative agreements between Israel and its neighbors. Failure to adequately address this problem will undoubtedly lead to increased tensions and possible military confrontation in the region in the future (Ze'ev Schiff, 1989, p. 22).

Before the middle of the next century the region may need four times as much water as it is receiving now from natural sources (The Economist, 1996). The regional water balance is expected to turn negative already by coming years. Israel, the West Bank and Gaza will face water shortage by 2020 while Jordan will theoretically see first signs of shortage after 2015.

Both Jordan and Syria face grave water shortages. The Syrian capital of Damascus goes without water on most nights and loses about $30 \%$ of its water supply due to a leaky pipe system. Syrian and Jordanian officials have planned to build a \$350 million "Unity Dam" on the Yarmouk River. Israel which receives 3\% of its national water supply from the Yarmouk River will not approve the construction of the dam unless it can be assured of its continued access to Yarmouk River waters. The World Bank does not extend financial support for international water projects unless all riparian consent. While such a project would greatly benefit Israel, Jordan and Syria, mistrust and political haggling have prevented agreements (Douglas Davis, 1990, p. 9).

The Israeli-Jordanian peace treaty signed on 26 October 1994 contains what amounts to a detailed water agreement between the two sides. The agreement would help The Hashemite Kingdom of Jordan overcome its water shortages, especially in the household sector.

Jordan is concerned with Israeli plans to build a canal connecting the Dead Sea and the Mediterranean (the Dead-Med Canal). The Jordanians predict that the subsequent rise in the level of the Dead Sea would prevent, or at least inhibit, the extraction of phosphates and other chemicals, would prevent the reclamation of the Wadi Araba for agricultural use and would pollute much of the Jordan valley's fresh water supply (John K. Cooley, 1984, p.5 ). A further plan between Jordan and Israel is that of establishing a new canal to link the Dead and Red Seas (Canal of the two Seas). The benefit of this canal will be immense as it will revive the arid area of Wadi Araba, where the two sides signed their peace agreement in 1994 (Al-Majalla, 1998, pp. 45-47).

Among all the riparian, the Palestinians face the toughest challenge from the Israelis. For one thing, their location in relation to Israel is downstream whereas Syria and Lebanon are upstream while Jordan is upstream on the Yarmouk River and downstream on the Jordan River. Furthermore, the Jordanian-Israeli agreement exhausts the available unused water, since most of the water Israel has agreed to give back to Jordan is floodwater. The Palestinians will have the hard task of reclaiming from the Jordan River basin their share of water that Israel is already exploiting. And if they hope to resettle hundreds of thousands of refugees in the occupied lands, their demand for water is bound to surge (Jerusalem Post, 1995).

Another complication for the Palestinians is the fact that the two sides have another major water conflict over the ground water resources recharged primarily from the West Bank but exploited for the most part by Israel. The Jordan River basin is shared by four countries, Israel, Jordan, Syria and Lebanon. It consists of four principal tributaries that are the headwaters of the river system, and one stem - the upper and lower Jordan River. The Hasbani, Dan, and Banias flow near snow - capped Mount Hermon, (Jabal El Sheikh ) Sheikh' is the Arab word for Old Man. Snow-capped Mount Hermon resembles an old man wearing a white cap, hence the name). These tributaries rise in Lebanon, Israel and Syria respectively, and flow south to form the upper Jordan River which flows into Lake Tiberius, the only natural reservoir within the basin. The Western and south-eastern shores of the lake are in Israel, while the north-eastern shore touches the Syrian Golan Heights. The Yarmouk River, the 
largest of the four principal tributaries, rises in Syria and flows south and then east into the lower Jordan River. The Yarmouk River forms the boundary between Jordan and Syria and then, further downstream, between Jordan and Israel, before flowing into the lower Jordan River. The lower Jordan River forms the boundary between Jordan and Israel in the north and south. In the center it forms the boundary between Jordan and the West Bank. The lower Jordan River discharges into the Dead Sea, which is shared by Jordan to the east and by the West Bank and Israel to the west. Upstream states can starve out downstream states by cutting off their supply or they can pollute the waters downstream by dumping toxic waste into the river.

With its occupation of the West Bank, Israel came to share a longer border with Jordan along the Jordan River. The rich ground water sources are now within Israel's jurisdiction and Israeli water policies have prevented, or retarded Palestinian agricultural development (Joyce R. Starr, 1991, p. 27).

The uneven distribution and overall availability of water in the region makes it a highly sensitive security concern. Consequently, the Working Group on water faced difficulties at the outset. Israel initially favored a focus on technical matters, such as resource management - while the Arabs wanted to negotiate water shares and rights. Israel resisted this agenda and contended that such rights were security questions that should be discussed in bilateral talks. The Syrian boycott further complicates comprehensive diplomatic efforts in this field. Syria's absence hinders discussion on basin-wide cooperation on the Jordan River and Yarmouk River, in which Damascus would be a major player.

At the Madrid Peace Conference water was recognized as one of the most substantive issues of concern to both Arabs and Israelis. Water resources working group was created within the framework of the multi-track of peace process. It would be fair to say that until the signing of the Rabin-Arafat Declaration of Principles on interim self-government, there had been little substantive progress made in the water resources working group. Even the Jordan-Israel peace agreement was not merely intended to end the state of war between them but also to open up an era of cooperation in a number of areas, including water resources. Under the terms of the treaty, Israel agreed to allow more water to flow to Jordan River as well as to store water in the rainy winter months and channel it to Jordan during the dry summer period.

The struggle for access to, and control over, water supplies has consistently provoked tensions and conflict between communities and nations. But if the parties involved in the struggle for access to scarce water were to perceive a mutual benefit in sharing the resource, then perhaps that resource could become the vehicle for cementing cooperative relations among them.

Water-politics is hitting up on the same lines as oil politics had earlier. In West Asia nine out of fourteen countries are water scarce. It is predicted that by the end of this decade water problems in the region would lead either to an unprecedented degree of cooperation or a combustible level of conflict. The Late Egyptian president Anwar El-Sadat had issued a warning in the spring of 1979 when he said that "the only matter that could take Egypt to war again is water".

The water problems facing the Palestinians and Israelis are even more intertwined. While Israel finally recognized in the September 1995 interim accord with the PLO that the Palestinians possess water rights, the reality is that the Jewish settlers consume four times more water per capita than do the West Bank Arabs, about 368 liters per capita per day, as opposed to roughly 88 liters in the West Bank (Note that a per capita consumption of 100 liters of water per day is generally considered to be the minimum for an acceptable quality of life).

The Syrian view is that no negotiations with Israel on water are possible until Israel withdraws from the occupied Arab lands particularly the Golan Heights. Lebanon, too, is opposed to any proposal to export the Litani waters and insists that its water supplies are not negotiable. Since Lebanon refuses to negotiate with Israel on a bilateral basis, the problem will have to be dealt with at the multi-lateral level if the peace settlement has to assume a comprehensive character. Successful talks among Israel, the PLO, Syria, Jordan and Lebanon over the fair distribution of water resources will provide sufficient credibility to the Arab-Israeli peace process.

\subsection{Arms Proliferation and the Nuclear Issue}

The vulnerability of Arab states against Israel's nuclear capability is considered as a determining factor in the Arab-Israeli peace. Arab ambition to get back occupied areas from Israel by force proved to be unattainable because of Israel's strategic superiority in both conventional and mass distraction weapons. Therefore, the nuclear deterrent of Israel is not only a source of instability but an impediment to Arab willingness to enter into peace treaties with Israel.

Earlier, Egypt had refused to sign the Nuclear Non-Proliferation Treaty (NPT) document unless it was also 
signed by Israel (Douglas Jehl, 1995). Despite Israel's ambiguous position on its nuclear capability, the issue of nuclear disarmament could gain priority in the Arab-Israeli normalization process. At some later stage, the Arab countries may get US support for the pursuit of nuclear disarmament in the region.

Israel is counted as one of the most dangerous nuclear weapon states in the region, the Dimona nuclear reactor being a vital source of materials for Israeli nuclear weapons. This reactor was established in December 1963. Its power is around 26 megawatts, which can produce about $8 \mathrm{~kg}$ of plutonium every year. Since January 1988 the Dimona reactor has produced more than $192 \mathrm{~kg}$ of plutonium which is enough to manufacture some 24 bombs (Peter Pry, 1984, pp. 66-79).

According to Mordachai Fa'anono, an Israeli Nuclear Scientist who was working for 10 years in the Dimona nuclear research centre, Israel has produced around 100 nuclear bombs (The Sunday Times, 1986) He added that the Dimona nuclear reactor produces around $40 \mathrm{~kg}$ of plutonium every year and Israel might produce Hydrogen Bombs (The Sunday Times, 1986).

The CIA reported in 1976 that Israel had produced between ten and twenty nuclear bombs (the New York Times, 1976). And more than 13 nuclear bombs were reportedly prepared by Israeli forces to be used in the October 1973 war (The Asian Age, 1998, p. 5).

\subsubsection{The Israeli Approach to the Nuclear Question}

According to the former Israeli Defense Minister, Ariel Sharon, nuclear deterrence is a very important issue for the present and future of Israel. Israel cannot permit the Arabs, to manufacture and stockpile nuclear weapons, as its very existence is at stake (FBIS-MEA, 1981, pp. 1-17). Both Menachem Begin and Yitzhak Shamir, former Israeli Prime Ministers, had suspected that the Arabs favored a policy of nuclear balance of terror in relation to Israel. The Iraqis were suspected of plotting another disaster for the Jewish people (FBIS-MEA, 1981, p. 12). However, other Israeli leaders were doubtful that the nuclear weapons of terror would be stable. According to Martin Van Creveld, Professor of Israeli Military History, the prospect of destruction on both sides (Arabs and Israelis),following a nuclear attack is not quite the same, and this will create instability in the region. Egypt or Syria might be able to withstand a nuclear bomb or two but not Israel (Martin Van Creveld, 1977, p. 123). As Arye Naor, General Secretary of the Israeli Labor Party put it, "Israel is a small country in size, so it may be totally destroyed by only two or three nuclear bombs" (Naor, 1987).

Some Israeli leaders have questioned the validity and import of some of the Arab leaders' ideologies. According to them, the genesis of the Arab-Israeli conflict is rooted in certain principles of Arab nationalism which prevent the Arabs from following realistic policies (Daniel Heradstveit, 1979, p. 62) According to Yigal Aloun and Aril Sharon, "Arab leaders are friendly and wise", but in the opinion of the former Defense Minister Moshai Arrnz "many of them are mad and cannot be trusted" (Uri Bar Joseph, 1982, pp. 220-22).

Those Israelis who supported the idea of nuclear deterrence believed that the balance of terror between Israel and its neighbors would be stable. In which case, it would be very difficult for either side to find justification for provoking a totally unacceptable destruction in case of a nuclear confrontation (New Outlook, 1982, p. 46). Thus the Israeli scientist, Shai Feldman, claimed that Arab-Israeli nuclear deterrence would be vital, stable and credible (Shai Feldman, 1982, pp. 71-168).

\subsubsection{The Arab Approach to the Nuclear Question}

In the past, the late Egyptian President Anwar El- Sadat announced that Israel would be the loser, if it started developing nuclear weapons (Al-Ahram Newspaper, 1995) He added that Egypt might lose one million but 39 million of the Egyptian population ( 80 million is now) would survive in the event of a nuclear attack. But if Israel lost one million it would be a total disaster (The Guardian, 1977). The Arabs could bear any nuclear attack given their large population but Israel could not bear any similar attack (Al Ahram Newspaper, 1976).

According to Mohammad Hussainin Haikel (an Egyptian Thinker), the small size of Israel meant that one nuclear attack would be deadly. Haikel described such weapons as an "Ugly Ghost" especially in Israeli hands. In Haikel's view, those hands were controlled by an archaic and frustrated psychological outlook that was colored by the suicidal ideology, that history was turning against Israel (Mohammad H. Haikel, 1977, p. 19).

Arab leaders view their acquisition of chemical weapons and ballistic missiles as legitimate in the face of the Israeli nuclear threat. Furthermore, since Arab nuclear capabilities are limited and are unlikely to match Israel's for many years, emphasis on chemical weapons as a counterforce seems logical (Shelley A. Stahl and Geoffery Kemp, 1992).

In July 1988, the former head of Egypt's Chemical Warfare Department, Mamdouh Ateya, argued that the Arab 
countries should acquire chemical and biological weapons as a counter to the Israeli nuclear capability as a longer-term goal. He stated that a chemical and biological Arab force could provide a temporary protective umbrella until the Arabs achieved nuclear parity with Israel and argued that the resulting balance would be stable (Reuters, 1988)

After the Gulf war of 1991, the region remains the world's largest arms importer and the regional states possess not only conventional systems but also chemical, biological and, in the case of Israel, nuclear capabilities. Thus the Arms Control and Regional Security Working Group (ACRSWG) confront the toughest task of all the multilateral groups. To succeed in its task it must overcome decades of military conflict and suspicion and convince its participants that cooperation in arms limitation does more good than harm.

The conferees initially concentrated on familiarizing themselves with arms control measures. Seminars were held for confidence-building and there have been a number of achievements in this area. In May 1993, the countries involved agreed to explore cooperation in air-sea search, crisis communication, pre-notification of troop movements and the exchange of information regarding defense budgets. They also agreed to establish a regional communications system tied to the OSCE (Organization for Security and Cooperation in Europe) network. Regional Conflict Prevention centers are planned in Tunisia and Qatar. Their objectives will be crisis prevention, management and resolution.

Yet the working group faces serious obstacles. The Arab countries, particularly Egypt want to link Israel's unacknowledged nuclear program to any reduction in conventional and non-conventional arms. Since 1974, Egypt has advocated a nuclear weapons free zone in the region and has refused to sign chemical weapons pacts until Israel agrees to curb its nuclear weapons program. Israel maintains that until the entire region is part of a comprehensive peace and arms control regime, the fear of nuclear reprisal is a deterrent Tel Aviv is unwilling to give up.

This disagreement between Israel and Egypt spilled out of the multilateral group and into the UN throughout 1994 and 1995 as the international community deliberated the extension of the Nuclear Non-Proliferation Treaty (NPT). Egypt and most of the regional states have signed the original documents, while Israel has not. During the NPT's extension, Cairo tried to link its own future adherence to the NPT with an Israeli agreement to join the treaty, a position from which it ultimately backed down under US pressure in May 1995. This dispute seriously paralyzed the working group. In fact the multilateral negotiations have essentially been reduced to the smaller intercessional meetings, the last one of which was held in September 1995.

In cooperation with the U.S., Israel has pursued the Arrow, an Ant tactical Ballistic Missile (ATBM) program. The Arrow is a Theatre Missile Defense (TMD) system, designed, primarily to destroy ballistic and cruise missiles that may be fired at the Jewish state. It is the largest defense project in Israel and is considered the "centre-piece" of U.S.-Israeli "strategic cooperation" by the American Israel Public Affairs Committee (AIPAC). The experimental Arrow Missile was to be designed to destroy ballistic missiles with ranges of at least 600 miles by intercepting them at a high attitude and at a range of 40-50 miles (Marvin Feurwerger, 1991, pp. 25-7).

For years, Israel has violated the Arms Export Control Act (AECA) and related executive agreements (Clyde R. Mark, 1994, p. 5). The CIA reports that China "seeks from Israel advanced military technologies that U.S and western firms are unwilling to provide" (Richard A. Bitzenger, 1991, p. 33).

There are concerns about Israel's handling of Arrow technologies. Israel may have transferred Arrow technology illicitly to at least one country. Equally disturbing, the former head of Israel's Arrow program, Dov Raviv, was convicted in April 1993 by an Israeli court for accepting bribes from a Canadian supplier of components. Some U.S. officials believe Raviv compromised the security, of the Arrow Project (Hugh Orgel, 1993, pp. 4-5).

In the perception of Syria, Israel has been able to dominate the region both on the battlefield and in the conference halls, because of its military superiority. Thus, rather than bowing to Jerusalem as Egypt's late President Anwar El-Sadat was seen to have done, the Arabs need to build up their military power in order to confront Israel from a position of strategic parity (Moshe Ma'oz Asad, 1988, pp. 178-183).

Syria has the most advanced chemical weapons program in the Arab world, including missiles capable of delivering chemical warheads to any part of Israel, and it possesses one of the largest stockpiles of chemical weapons in the Third World. Syria has also tested a domestically produced Scud missile for the fourth time.

Thus, we can say that the region is in danger unless all the nations of West Asia cooperate with one other to save it from disaster. This means controlling the arms race and ridding the region of weapons of mass destruction. Now-a-days, it is relatively easy for any country to acquire nuclear weapons and it is not only Israel which is capable of such acquisition but the Arab world as well, as the latter has the oil wealth to make that possible. 
Moreover, West Asia suffers from a certain degree of irrationality that seems to affect certain leaders of the region. These leaders who tend to function more on the basis of personal ambitions and the personality cult than on rational calculations. Thus the risk of arbitrary decisions that could lead to a nuclear catastrophe is great (Amin Al-Hwaidi, 1983).

\subsection{The Environmental Issue}

The Madrid multilateral group meeting presented a fresh opportunity to encourage closer environmental cooperation. In May 1993, the sides identified clusters of issues, such as environmental awareness, desertification, sea pollution and sewage waste disposal that required attention and assembled committees to discuss each cluster.

The first breakthrough came in November 1993 when Israel and Jordan agreed to cooperate on pollution and oil spills in the Gulf of Aqaba, as well as management of the Gulf's picturesque coral reef.

In 1994, the multilateral group participants solicited and received from the World Bank funding for a project to tackle the problem of desertification. In October 1994, an Environmental Code of conduct and cooperation was adopted unanimously at a meeting in Bahrain. Each state pledged to follow development of adjacent countries. At a June 1995 gathering in Amman, discussions centered on disposal of wastes and hazardous materials and on plans to construct a permanent environmental research center in Jordan or Bahrain.

Concerning Israel's nuclear activities, Cairo maintains that the former nuclear program coupled with its disposal of radioactive materials threatens the Sinai and surrounding areas; and it wants these activities to be supervised by the Environmental group. Israel believes that Egypt is simply looking for a way to examine its nuclear program, and wants the matter referred to the arms control working group. This issue remains unresolved to date.

Moreover, Israel has disposed of some 60,000 tons of toxic wastes from a Haifa factory in the Mediterranean Sea. These wastes were transported in Norwegian ships, although Norway is a signatory to the International Agreement which outlaws the disposal of harmful materials in rivers and seas. Significantly, Israel has refused to sign the agreement dealing with environmental security in West Asia (Addustour Newspaper, 1998, p. 24). This is storage, given that Israel is a part of this region and the health and safety of its population are closely tied up with those of other populations in the region.

\subsection{The Golan Heights Issue}

Syria is now the frontline Arab state which has not entered into a peace agreement with Israel (Front-line Arab state here means a neighboring country that is still in a state of war with Israel). Therefore, the focus of the US-led peace process in the region is now an early rapprochement between Syria and Israel. On these grounds, peace between Israel and Syria is considered essential for the completion of the regional peace process.

The bone of contention between the two countries is the Golan Heights. For a long period of time, Syria maintained a position of not negotiating a peace agreement with Israel unless the later returned the Golan Heights. Earlier, Syria was demanding that Israel withdraw from all of the Golan Heights and Israel was demanding that Syria consent to a full-fledged peace with full diplomatic relations and trade.

There can be no final peace in the region without a peace between Syria and Israel. The Israeli government has expressed its wish to resume negotiations with Syria. The Syrians have also said that they want to get back to the negotiating table. Both Israelis and Syrians had reached a decision that peace was a strategic goal that must be attained. On November 3, 1996, the Late Syrian president Hafez Assad stated that "peace remains a strategic option for Syria" (Tishrin Daily Newspaper, 1996).

The difference on withdrawal is significant in that Syria's demands would give it access to the Sea of Galilee, which is the principal water reservoir for Israel, and the problem of water in the region is as acute as that of territory (David Kimche, 1996).

Differences also exist over security issues. Topography has given a key advantage to the Syrians as the Golan Heights dominate the entire northern Galilee. But the bottom line is that the Israelis distrust Syrian intentions. They point to the fact that Syria does not have a democratic regime and there is no way of knowing whether Assad's successor would respect a peace agreement signed by him. Israel, therefore, wants to compensate the prospective loss of the Golan Heights by iron-clad security arrangements which would include a significant reduction in the size of Syrian forces facing Israel, demilitarization of the Golan and early warning stations.

Ever since Netanyahu was elected Prime Minister, Syria has been one of his harshest critics, flaying his stand on the principle of exchanging land for peace and even likening him to Hitler. "Electing Netanyahu exposes Israel as a war-loving country", the English language daily Syria Times said soon after his election. It is really tragic to 
see a hawk like Netanyahu winning the elections by winning the confidence of the majority of the people who should be ashamed of preferring war to peace. The main Arabic language dailies, Tishrin and Al-Thaura, have urged Washington to intervene to salvage the peace process (Sunday Telegraph Newspaper, June 2, 1996).

In order to restart negotiations with Syria and Lebanon, Netanyahu brought forward the proposal of "Lebanon First". This proposal would be followed by territorial withdrawal on the Golan Heights, allowing Syria to keep its control of Lebanon. It was clear, however that Netanyahu wanted the negotiations mainly to discuss Israel's security problem in South Lebanon and not so much its withdrawal from the Golan Heights.

Meanwhile, the former Lebanese President Elias Hrawi and the Late Syrian President Assad agreed to adopt a common stand on peace moves with Israel during talks in Damascus on August 5, 1996. Hrawi said he was opposed to the Israeli offer of "Lebanon first" which Syria described as a trap aimed at sabotaging the good ties between Damascus and Beirut. And a few days later, Syria announced that it rejected Israel's offer to resume peace talks on a "Lebanon first" basis before making full peace with Damascus. Syria and Lebanon need to act at the same time, in the same step, Assad announced at a news conference after talks with Egyptian President Hosmi Mubarak in Alexandria on August 7, 1996. He said Netanyahu's offer submitted via the US, raised little hope of resumption of peace talks between their countries and insisted that Syria would not cede an atom of Golan soil (Jerusalem Post, 1996).

When it was clear that Assad was not going to go for the "Lebanon first" offer, Netanyahu urged Assad to forget the Golan Heights and console himself with "water and security only", with an Israeli withdrawal from the security zone in Lebanon as an added dividend. But according to Abba Eban, former Israeli Foreign Minister, "Assad already has water from the Euphrates and Orontes Rivers and neither does he have any pressing security concerns. He said that the security zone is an Israeli headaches and the liberation of Israel from its headaches has never been a Syrian priority" (Jerusalem Post, 1996).

According to Israelis, Assad didn't really want peace but only a peace process that allows him to continue talks under US auspices; and that he was quite content with the present situation in Lebanon continuing rather than any change on the Golan Heights. At that time, Beirut was a satellite state, whose leaders were regularly summoned to Damascus for instructions. Some 35,000 Syrian troops were stationed in Lebanon ostensibly to protect the country but really to establish a "Syrian order" Assad can control Hizbullah terrorism against Israel from Damascus without taking responsibility for the organization's actions. If peace was achieved in Lebanon, Syria would risk losing all these benefits (Jerusalem Post, 1996).

There are many Israelis who believed that Assad cannot afford to accept peace, at least not in the fullest sense of the term and that the peace he had in mind is very different from that which Israel asks for. It is rather more of a non-belligerency pact than a full normalization of relations. The reason they put forward is that the Alawite sect to whom Assad belongs, makes up less than $12 \%$ of the Syrian population, yet rules over Syria with an iron hand. A Syria at peace would be a changed Syria, much more open to outside influences, including democracy, which in turn could mean the end of Alawite hegemony the Israelis believed (David Kimche, 1996).

The peace process between Syria and Israel also hinges upon the crucial question of return of the occupied land and the future of the Israeli settlements in the Golan Heights. The question of the Golan Heights is complicated by the fact that Israel has sought to establish settlements there and extend Israeli laws and jurisdiction to that area.

Today, Israel has established several large scale settlements in the Golan Heights. Given the present trend in Israel's domestic politics, no Israeli government can ever hope to renounce either its claim over the Golan Heights as part of the "land of Israel" or to evacuate the settlements established there. Also, no Syrian government can accept this situation. Thus, the question of sovereignty over the Golan Heights, the framework, if any, for return of parts of the occupied territory and the future of the settlements are the main issues that hamper the Syria-Israel peace process.

Today, the Syria-Israel peace process is halted and the Palestinian-Israeli peace process is marking time on issues that are peripheral. The longer the peace process is delayed the greater is the chance of Israel's defacto annexation of occupied territories and of the present state-to-state talks giving way to a clash between religions and religion-based civilizations. That will change the very character of Arab-Israeli relations as well as of regional and international responses.

While the possibility of the eruption of war between Israel and Syria is rather weak, any potential war would be against the whole of the region and the peace process. Syria cannot win a war against Israel, but it could cause substantial damage. Moreover, there is an adage in West Asia that war against Israel is impossible without Egypt 
and peace with Israel is impossible without Syria. And the leaders of both Syria and Israel believe that the peace talks will move towards either breakthrough or stalemate. Both Israel and Syria want peace, but each wants it on its own terms. Israel and Syria hold divergent opinions about the comprehensiveness of any peace agreement that they might reach. Israel wants such an agreement to stand on its own and not depend on progress on other negotiating tracks. Syria, meanwhile, is officially committed to a comprehensive settlement.

Due to Syria's role in Lebanon, one can credibly argue that a breakthrough on the Israeli-Syrian track will lead to a breakthrough between Israel and Lebanon. The fate of Lebanon will be largely shaped by Israeli-Syrian relations. Lebanon will not move forward in its negotiations with Israel before Syria. Once an Israeli-Syrian agreement is reached, a trade-off regarding Lebanon will be possible.

There was no evidence that Late Syrian President Assad was prepared to accept half a loaf, when he had earlier rejected the Rabin government's offer to return most or even all of the occupied area in exchange for peace, security arrangements and a degree of normalization. Indeed, Assad's priority where to keep power for himself and the minority Alawite Sect that rules Syria. Similarly, there is no chance of an agreement between Israel and Lebanon. Lebanon was not an independent actor. Syria which continued to maintain thousands of troops there and wouldn't permit a separate peace between those two countries.

Lebanon could well be an opportunity for unilateralism on the part of Israel whose aims in Lebanon are security-related and not territorial. The Israeli military presence in the South of Lebanon had failed to deter rocket attacks against northern Israel. Moreover, Israeli forces themselves had increasingly become targets of Hezbollah attacks. Israel could simply pull its forces out. Withdrawal from Lebanon would reduce the vulnerability of Israeli forces and give Israel a major diplomatic accomplishment. It would put pressure on Syria and Iran to halt their interference in Lebanon's internal affairs and to stop arming or better yet, to disarm Hezbollah, something that would reduce the chances of both renewed fighting in Lebanon and of conflict between Israel and Syria.

The U.S. needs to be more active in the negotiations between Israel and Syria for the sake of its own strategic interests in the region. The former American President Clinton has said that "Without an Israeli-Syrian settlement we will never have comprehensive peace in the region" (Newsweek, 1994, p. 16). While without American help the peace process will not move forward positively, the US needs to change its policy towards the region, building on the two countries' desire for peace. It must recognize that Syria constraints in the peace talks. And the US should remove Syria from its list of 'Terrorist' states.

\subsection{The Issue of Fundamentalism}

For nearly half a century, West Asia has been a fertile hot-bed of international terrorism involving different groups and state sponsors. While the main fuelling element is the Israel-Arab conflict, perpetrators of terrorism differ in motives and ideological background, ranging from fundamentalist Islamic elements to left-wing Marxist-Leninist and nationalist cadres.

With the end of the Cold War and the collapse of the former Soviet Union, the situation has changed, making left-wing secular ideology less attractive to most Palestinians.

Today the main terrorist organizations operating against peace between the Arabs and Israel are Hamas(Hamas is the Arabic acronym for Islamic Resistance Movement), Islamic Jihad and Hezbollah, while from the Jewish side they are Cakh, Shas, and Meretz. The above named parties from both sides have proclaimed themselves religious fundamentalists.

A series of illegitimate and illegal acts of opposition were indulged in by several groups of Jewish fundamentalists who explicitly rejected the right of the Israeli government to surrender parts of the "holy land", to the 'gentiles'. For the fundamentalists, the land was promised by God to the people of Israel, therefore, no human being could barter away their right to inherit it. If someone is defined by their rabbis as a "betrayer", one who transfers Jewish land to the gentiles, a true believer has the right to take his life.

On September 13, 1993, at a Washington ceremony, some hardliner Jewish settlers announced the formation of a volunteer militia to "enhance security". They said, "This is Israel land-our homeland". At the same time Hamas issued a statement that said, "Yes to the Resistance and one thousand Nos. to the Agreement of humiliation and shame" (Time, 1995, p. 16).

Hamas, Islamic Resistance Movement, grew out of the Intifada, the Palestinian uprising against Israel in 1987 led by Late Sheik Ahmed Yassin, a quadriplegic religious leader. Ironically Israel did not oppose Hamas in its early stages, it view the group as a useful counterbalance to the PLO, not a potentially dangerous brand of radical Islam that would later seek to destroy the Jewish state. In 1989, Israeli authorities arrested Ahmed Yassin. The 
arrest opened the door to a younger, more activist and radical leadership. Yassin was suffering from a very bad condition in Israeli custody. Israel feared that if he died in an Israeli jail, it would be a disaster and hence he was freed in October 1997.

Rabin's banishment in late 1992 of more than 415 suspected Islamic militants to a no man's land in southern Lebanon backfired. Some deportees apparently learned how to make bombs there. Another lesson of their sojourn was the value of decentralization. Moreover, that move caused a groundswell of popular support for Hamas in the West Bank and Gaza. A year later, Israel permitted the deportees to return.

In February 1994, an immigrant Jewish doctor from America, Baruch Goldstrin, fired on a mass of praying Palestinians at dawn in the holy month of Ramadan at a place of worship in Hebron city, regarded as sacred by both Arabs and Jews and killed 29 Palestinians. Rabin's language after the massacre was categorical: Jewish radicals like Axe lard "are not parts of the congregation of Israel". Rabin told the Knesset, "Sensible Judaism spits you out". (Newspaper, 1994, p. 40). The killer went to the holy place in Hebron not just to kill Palestinians but to achieve a political goal: to kill the peace and to kill negotiations with the Palestinians (Newspaper, 1994, p. 42).

The killer, Goldstein, tried to destroy the Israeli-Palestinian peace process in his own way at a time when Late Arafat was waiting at the first road block on his way back home in Gaza from Tunis. The maniacal killer's grave has been turned into a shrine by his admirers. Goldstein, and Yugal Amir, who murdered Rabin, were convinced that they were acting under authority from God to prevent peace between Israelis and Palestinians. This, of course, is the lunatic fringe of Zionism.

Following the massacre at the Hebron Mosque, Hamas' militant military wing, the Qassam Brigade, began targeting Israeli civilians. In October 1994, Hamas kidnapped Israeli corporal Nahson Waxman. Israel negotiated with Hamas for his freedom in exchange for the release of 200 Arab prisoners. (Time, 1994, p. 28). To Israel, a Jewish person is equal to two hundred Arabs; Israelis are expensive while Arabs are cheap.

According to Sayeed Abu Uasamah, former editor-in-chief of the Hamas newspaper Al Wattan, "We love life, but life has no meaning if they want to make us slaves, so we believe that suicide bombings against Israeli targets are a must". According to the late chief of Hamas, Ahmed Yassin, "Palestine concerns the entire Arab nation Arab rulers, including Palestinians; do not have the authority to surrender even a part of Palestine. We oppose peace, reject the Jews and denounce whoever allies himself with America". Late George Habash, then General Secretary of the Popular Front for the Liberation of Palestine (PFLP), regarded the peace accord with Israel as a "trick to rob Palestinians of their legitimate rights". (Dan O'Neil and Dan Wagner, Peace or Armaggedon : The Unfolding Drama of the Middle East Peace Accord (Harper and Collins, 1993, p. 50). According to a Jewish hardliner, David Bar-Illan, the accord divided Palestinians into two categories, Arafat and his secular forces, and evil religious fanatics. And the second constitutes a danger for the future of Israel. Some Israelis refuse to accept the PLO as a negotiating partner and they regard the accord as a violation of Israeli law by Yitzhak Rabin. (Norman Podhoretx, 1994, p. 22).

The months of September and November 1995 were a trying period in the peace process. First in a major blow to the peace process, the leader of the Islamic Jihad Organization was killed by the Mossad. This act vitiated the atmosphere for both Palestinians and Israelis, causing fears of a reprisal. Secondly, the assassination of Rabin by a Jewish fundamentalist was an astonishing development. Rabin's death did not have an adverse effect on the peace process but it became clear that Israel would have to deal more and more with challenges coming from its own society in the future. As another important development the Palestinian National Authority by an overwhelming majority of votes decided to clamp down on Hamas. This led the Hamasleader to assert that "Arafat has allowed a new wolf into the sheep pen". The Palestinian Authority under Arafat has arrested hundreds Islamic suspects, including four of the thirteen men on Israel's most wanted list. Its security forces have conducted house-to-house searches in Ramallah, Bethlehem and Gaza, where they raided the bastion of Hamas, the Islamic University (The Economist, 1996). Of course, the late PLO leader Arafat was affected by the Rabin statement that "the peace process depends upon how the Palestinian Authority will prevent the Gaza strip from becoming a haven for terrorists" (Time, 1994, p. 35).

Yugal Amir, a law student at the religious Bar-Illan University, said that he killed Rabin because "he was giving away our home land"; some right wing Israelis said that "the people" do not want this peace and that God forbids any contact between Jews and the PLO (Newsweek, 1995, p. 23). Some of the most militant Zionist groups hastened to condemn the assassin Yugal Amir who insisted that his only prompter and helper was, God.

There had been warning of a plot against Rabin, but the security men were worried primarily about Arab assassins, not Jewish ones. They thought there might be an attempt to exact revenge for the murder of Late 
Islamic Jihad leader Fathi Shikaki who was killed in Malta by the Israeli Mossad on 28th October 1995 (Newsweek, 1995, p. 14).

The most astonishing developments of 1996 were the suicide bombings carried out by Hamas and the Islamic Jihad in Jerusalem, Ashkelon and Tel Aviv. These bombings led to a public reaction in Israel which endangered the continuation of the Oslo peace process and the prospects of then Israeli Prime Minister Peres winning the elections scheduled for May 29. And the Likud leader Netanyahu won the elections held on May 29, 1996. Those suicide bombings followed the murder of one of the Hamas leaders, Yahya Ayyash, known as "The Engineer", who was killed by a booby-trapped telephone presumably by the Shin Bet (Israeli internal security forces).

The bombings stopped the Israeli nation dead in its tracks. There was massive public frustration that peacemaking had not ended terrorist attacks at home. This revived among many Israelis the fear that peace with the Palestinians was not bringing them what they wanted most-security. This destroyed the voters' confidence and lent credence to rightist arguments that ceding territory to the Palestinians would lead to violence, not peace.

In order to combat the fundamentalists in the region, the summit of peace makers was held at the Egyptian sea-side resort of Sharm-El-Sheik on March 13-14, 1996. The Summit had three fundamental objectives: (i) to enhance the peace process; (ii) to promote security and (iii) to combat terror. The participants expressed support for efforts to ensure stability and prevent terrorist organizations from engaging in recruitment, supply of arms or fund raising; to exert maximum vigilance against these groups and cooperate in cutting them off, and to provide training, equipment and other forms of support to those taking steps against groups using violence and terror to undermine peace, security or stability. All countries agree that there is no uniform strategy to combat terrorism as groups operate differently in different places. No concessions should be made to terrorists. This is an international task involving all the countries around the globe because, as Peres said at Sharm-El-Sheik, "terrorism knows no borders, so borders must not restrain action to smash the terrorist snake" (ITN Source, 1996).

\section{Conclusions}

We may conclude that the ongoing peace process will depend on the establishment of the new state of Palestine. It is widely agreed that a stable and a democratic state in Palestinian territory is a must for peace and order in the region (Amos Perlmutter, 1994, p. 11). Only within the rules of democracy can both sides flourish in the newly shaping West-Asia region. Otherwise the reconciliation of Jews and Palestinians on a permanent basis may not be possible. The question of geo-cultural integration is still on the agenda. According to one stream of Israeli opinion, Israel will never be an integral part of the regional states, because the compromise it is making with the Arab people is diplomatic rather than historic. Hence it will remain suspicious and suspect. Therefore, Israel must not see itself, in the aftermath of the peace agreements as a part of the region, to hope to benefit from them. Arab culture will not link up with Israeli culture, not even with the help of bridges built by Jews who come from the Arab countries like Morocco, Yemen, and Iraq (Joseph Alpher, 1994, p. 241).

In fact, the Palestinian elite seem to realize that their best chances for an independent state lie in their adherence to democracy. It is not possible to integrate into a western led world community with a low level of political institutionalization and a fractural political structure in an unstable political climate (Edy Kaufmann and Shukri B. Abed, 1993, p. 48). The Israelis also should see their stakes in supporting the evolution of a democratic state in the Palestinian lands. It must be an important priority for Israel to ensure democracy in Palestine since that would guarantee the nature of relations as productive and cooperative (Edy Kaufmann and Shukri B. Abed, 1993, p. 44). The Palestinians should have an interest in seeing their neighbor Israel remain democratic in order to continue on their path that leads to an independent state. The assassination of Rabin and incidents during the withdrawal from the occupied territories have shown that the most obvious enemies of peace in Israel are extremist religious groups, overtly fascist and racist right-wing. On the Palestinian side, many agree that the radical groups such as Hamas and Islamic Jihad are enemies of peace. The local and international factors behind the Oslo Agreement are more powerful than the earlier peace attempts. The wave of suicide bombings executed by Hamas will not change this fact, but it has undoubtedly raised the price which Israel has to pay (Al-Ahram Newspaper, 1996).

All said and done, the relevance of democracy for the Palestinians cannot be over-stated. First of all, the Intifada served to diminish the authoritarian tendencies of Palestinian politics. Secondly, the influence of Jordanian and Israeli politics has increased democratic sentiments (William B. Quandt, 1994, p. 23). And finally, the western-educated Palestinian intellectuals admire many aspects of democratic political culture. Furthermore, they may play a major role in establishing a democratic Palestinian state (Kaufmann and Abed, 1993, p. 47).As an important advantage, there are no ethnic divisions in Palestinian society. The only apparent division seems to 
be between secular and religious groups.

Finally, a just, comprehensive and lasting peace is the hope of everyone in the region of West Asia. Thus, without a Syrian-Israeli rapprochement, a settlement on Jerusalem, an accord on water resources, conclusive talks on the return of the Palestinian refugees an accord between Israel and the PLO over an independent Palestinian state, an understanding on nuclear and environmental issues, full trade and economic cooperation, freed all the occupied lands and a full stop to fundamentalism, the regional peace process won't be succeed.

Moreover, the history and politics of the Arab-Israeli peace process has proved that the best methodology of resolving conflicts is the "land for peace" formula applied through the step-by-step approach and by external mediation. However, even after the settlement of core and peripheral issues in the Arab-Israeli conflict, one cannot predict conflict and tension free relations between the two peoples because the historical, regional and cultural discords between the Arabs and Israelis are hard to settle. What will happen is the pragmatic coexistence of Arabs and Israelis despite their mutual reservations and antagonisms. If Israel and its Arab neighbors cannot be good friends, they need not be enemies but partners in peace and human progress. Because of challenges and problems like the assassination of Rabin and the role of hardliners in Israel and the insecurity created by Hamas, the Arab-Israeli peace process has to deal with some tough issues in the years to come.

\section{References}

Abbas, S. (1993). In Search of a Durable Solution: Residency Status and Civil Rights of Palestinians in Host Arab States. Refugee Studies Program, Oxford University.

Ahmad, K. (1992). A Palestinian Settlement: Towards a Palestinian Doctrine of National Security", Israel-Palestinian Peace. Research Project Working Paper.

Al-Majalla. (1998). The Road to Peace. The International News Magazine of the Arabs, 5(3), 45-47.

Alon, P. (1994). Peace with Jordan. The Jerusalem Post.

Amin, A. H. (1983). The Arab-Israeli conflict: between the conventional deterrent and the Nuclear deterrent. Beirut.

Amos, P. M. (1994). Arafat's Police State. Foreign Affairs, 4, 11.

Antonio, C. (1993). Some Legal Observations on the Palestinians, Right to Self-Determination. Oxford International Review, 4(1), 10-13.

Arye, N. (1987, August 7). A Strategy to meet the Nuclear Danger. The Jerusalem Post, p. 13.

Boyle, F. (2009). Palestine, Palestinians and International Law. Atlanta, GA: Clarity Press.

Chomsky, N. (1999). Fateful Triangle: The United States, Israel, and the Palestinian. Cambridge: South End Press.

Christenson, K., \& Bill, C. (2009). Palestine in Pieces: Graphic perspectives on the Israeli Occupatio. London: Pluto Press.

Clyde, R. M. 1994, February 24). Israel: US Foreign Assistance. Congressional, Research Service, CRS, p. 5.

Dan, O., \& Dan, W. (1993). Peace or Armageddon: the Unfolding Drama of the Middle East Peace Accord. London: Harper and Collins.

Daniel, H. (1979). The Arab-Israeli Conflict: Psychological Obstacles to Peace. Oslo: Universities for Laget.

David, K. (1996). Arab-Israeli Peace Process. Security Dialogue, 27(2).

Donald, N. (1995). Clinton Places US Policy at Israel's bidding. Middle East International, 7, 15-16.

Donna, A., \& Karen, Z. (1993). Return of the Negotiated Lands The Likelihood and Legality of a Population Transfer between Israel and a future Palestinian State. Journal of International Law and Politics, 24(4), 1445.

Douglas, D. (1990, June 9). Water shortages could lead to war. Jerusalem Post (International Edition), p. 9.

Douglas, J. (1995, April 6). Clinton Presses for Nuclear Free Mid- East. The New York Times, p. 11.

Economic Digest, November 4, 1994.

Edward, A., \& Chung-In, M. (1988). Towards an Alternative Conceptualization. In E. Azar, \& C. Moon (Eds.), National Security in the Third World: The Management of Internal and External Threats. London: Edward Elgar. 
Edy, K., \& Shukri, B. A. (1993). The relevance of democracy to Israeli-Palestinian Peace. In E. Kaufmann, S. B. Abed, \& R. L. Rothstein (Eds.), Democracy, peace and the Israeli- Palestinian conflict (p. 48). London: Lynne Rienner Publishers.

Fida, N. (1983). Middle Eastern Waters: The Hydraulic Imperative. Tel Aviv: Jaffee Center for Strategic Studies.

Fida, N. (1990). Middle Eastern Waters: The Hydraulic Imperative. Middle East International, April, 16.

Haikal. M. H. (1996). Jordan-Israel Peace: the Terms of the Peace Treaty. Middle East Journal of Palestine Studies, 21(3), 23.

Hugh, O. (1993). Ex Head of Arrow Missile Project found Guilty of Accepting a Bribe. Jewish Telegraphic Agency, April, 4-5.

John, K. C. (1984). The War over Water. Foreign Policy, 54, 5.

Joseph, A. (1994). Israeli's Security Concerns in the Peace process. International Affairs, 2, 241.

Joyce, R. S. (1991). Water Wars. Foreign Policy, 82, 42.

Martin, V. C. (1977). Military Lessons of the Yom-Kippur War.

Martin, V. C. (1977). Military Lessons of the Yom-Kippur War. The Jerusalem Quarterly, 5, 123.

Marvin, F. (1991). The Arrow Next Time? Israel's Missile Defense Program for the 1990's. Washington, DC: Washington Institute for Near East Policy.

Mohammad, H. H. (1977). The Solution and War. Beirut.

Moshe, M. A. (1988). The Sphinz of Damascus. New York: Weidenfield and Nicolson.

Neil, K. (1949). A Tale of Two Cities. The Rhodes and Lausanne Conferences, pp. 25-26.

Norman, P. The Peace Process so far. Commentary, 6, 22.

Peter, P. (1984). Israel's Nuclear Arsenal. (Colorado):West View Press, pp. 66-79.

Public Attitudes towards Events in the Middle East (pp. 1-4) (1992). Princeton, NJ: Gall up Organization.

Richard, A. B. (1991). Chinese Arms Production and Sales to the Third World. Santa Monica, CA: RAND Corporation.

Richard, W. B. (1993). The future of the Islamic Movement. Foreign Affairs, 72(5), 38-44.

Saul, C. (1983). Israel's Defensible Borders. Tel Aviv: Jaffee Center for Strategic Studies, p. 29.

Shai, F. (1982). Israel Nuclear Deterrence: A Strategy for the 1980s. New York: Columbia University Press.

Shelley, A. S., \& Geoffery, K. (1992). Arms control and Weapons proliferation in the Middle East and South Asia. New York: St. Martin's Press.

Shlaim, A. (1995). War and Peace in the Middle East: A Concise History. New York: Penguin.

Shomlo, B. A. (1992). Opening Remarks, Official Presentation by the Israeli Delegation to the Refugee Working Group of the Middle East Peace Talks. Ottawa.

Starr, J. (1991). Water Wars. Foreign Policy, 82, 17-36.

Uri, B. J. (1982). Nuclear Doctrines in the Middle East. The Journal of Strategic Studies, 5(2), 220-222.

William, B. Q. (1993). Peace and Process: American Diplomacy and the Arab-Israeli Conflict since 1967. Washington DC: The Brookings Institution.

William, B. Q. (1994). The Urge for democracy. Foreign Affairs, 4, 23.

Yoav, P. (1992). Ethnic democracy and the Legal construction of Citizenship: Arab Citizens of the Jewish State. American Political Science Review, 86(2), 432-443.

Ze'ev, S. (1998). Security for peace: Israel's Minimal Security Requirements in Negotiations with the Palestinians. Washington, DC: Washington Institute for Near East Policy. 